\title{
The Confederazione Italiana Archeologi social media projects during the Covid-19 pandemic in Italy: changing the digital communication approach to the online community.
}

\author{
Nicolò Donati ${ }^{1}$, Elisa Gusberti ${ }^{2}$, Tommaso Magliaro ${ }^{1}$, Alessandra \\ Riva $^{3}$ \\ ${ }^{1}$ Independent Researcher \\ ${ }^{2}$ Soprintendenza Speciale Archeologia, Belle Arti e Paesaggio di Roma \\ ${ }^{3}$ MOLA (Museum of London Archaeology)
}

\begin{abstract}
With the onset of the Covid-19 pandemic, social media has rapidly become a crucial communication tool for sharing information with the public. In this article, we shall examine two media projects: \#CLAndremo and Una domenica al museo launched on the social media pages of the CIA - Confederazione Italiana Archeologi following the lockdown stages in Italy in 2020. \#CIAndremo is the first original project that our association released on Facebook, Instagram IGTV and YouTube during the pandemic, responding to the social campaign \#iorestoacasa (I stay at home) as a measure to contain the epidemic outbreak. We will present the methods and procedures used to produce the videos, the limitations we faced because of the lockdown and the final positive feedback received from the public. The second project was the enhancement of Una Domenica al Museo (Sunday at the Museum), a weekly column born on the CIA Instagram profile, which is advertised with the hashtag \#unadomenicaalmuseo. Here we are presenting the adaptation of the format that followed the Italian government lockdown restrictions and how it also changed the interaction with the public.
\end{abstract}

Keywords: Communication, Heritage, Pandemic, Public Archaeology, Social Media

\section{Introduction}

This paper discusses two media projects promoted by the Confederazione Italiana Archeologi (hereafter CIA): \#CLAndremo and Una domenica al museo launched on the social media pages of the association following the various phases of the lockdown in Italy in 2020. The lockdown measures were first put in place in the territories affected the most: the regions of northern Italy such as Lombardy, Piedmont, Veneto and Emilia-Romagna where the

CONTACT: Nicolò Donati, nicolo.donati1@gmail.com; Elisa Gusberti, elisa.gusberti@beniculturali.it, Tommaso Magliaro, tommaso.magliaro@gmail.com, Alessandra Riva, ariva@mola.org.uk 
outbreak of the virus reached the highest levels by the end of February 2020. The government established a series of strict containment measures for these territories: prohibition of leaving, suspension of all events, educational services and schools of all levels, museums and public offices, commercial and work/business activities except for those that provide essential services. On the night of 9 March, Giuseppe Conte, the former Italian Prime Minister, spoke to the nation about the danger of the spread of COVID-19 as cases surged nationwide and extended the restrictions to the whole country. Initially, all non-essential businesses were closed, and people were ordered to stay at home, permitted to leave for essential purposes only. In the Lombardy region, the centre of the major outbreak of the virus, activities were closed 15 days before the government announcement. The health emergency caught Italy off guard, paralysing the whole country and the majority of activities, businesses, travels and events could not be carried out normally as for all the CIA programmed activities that suddenly stopped. As a result, the lockdown has led the members of the association to rethink the planning of the activities by shifting to a digital format and eventually unlocked a new communication strategy by engaging users in original projects and online events. To better describe our projects, we decided to start from the original project following the Italian government campaign \#iorestoacasa (Bozza, 2021) during the first lockdown: \#CIAndremo, and then consider the methods and procedures used in gathering the material to produce the videos and the limitations that the CIA Communication Group faced during its processing. Then, we are going to examine the improvement of an existing weekly column born in 2019 on the CIA Instagram profile called una domenica al museo, following the closure of Italian museums during the first and the second lockdown, interspersed by the short summer reopening. In the conclusions, insights illustrating results will be discussed aiming at explaining the exponential growth of the public engagement on the CIA social media channels during the various phases of the pandemic in Italy.

\section{The Confederazione Italiana Archeologi social media communication}

This study is authored by the members of the CIA Communication Group ${ }^{1}$ and aims at critically discussing the social media insights derived from two projects in which the group dedicated its energies during the pandemic. But first, we are going to illustrate the background that led the Confederazione Italiana Archeologi to become one of the biggest archaeologists' associations in Italy and how social media changed the interactions between members during the sixteen years since its foundation in 2004. Since the beginning, the CIA has sought to represent all archaeologists operating in Italy: including Ministry of Culture employees and self-employed archaeologists, as well as university students, professors, researchers, and owners of archaeological companies. Its founders believed in changing romantic perceptions of archaeology among the general public, particularly where archaeology was regarded as a hobby, rather than as a profession and 'real job'. During all those years, changing this collective opinion wasn't easy and, since

\footnotetext{
${ }^{1}$ At that time our team consisted of F. Del Fattore, N. Donati, E. Gusberti, D. Mancini, T. Magliaro, A. Riva. Also A. Abbadessa, M. Crudo, D. Danelli, F. Dell'Era, A. Pintucci, L. Romoli, M. Stacca are credited for helping contribute to this project.
} 
the beginning, the main effort of the founders has been to legitimise the archaeological profession before the law and then to the general public. The promotion was the key to acknowledging the association's constant work all over the years until the important milestone of the recognition of the profession before the law on 25 June 2014, when The Italian Parliament passed a bill (Law 110/2014) recognizing and defining cultural heritage professionals as qualified persons who intervene in the protection, conservation, development, and enjoyment of cultural property (Levush 2014). Cultural heritage professionals include archaeologists, archivists, librarians, art historians, and restorers, among others. Something changed when the internet started to be used as a worldwide platform for the exchange of information and became widely available. Starting in the early 1980s and continuing to this day, the Internet grew beyond its primarily research roots to include both a broad user community and increased commercial activity (Leiner et al. 2009: 12). The turning point was the introduction of a new communication system in the late 1990s: social media networks. These web-based services allow individuals to construct a public or semi-public profile within a bounded system, articulate a list of other users with whom they share a connection, and view and traverse their list of connections and those made by others within the system. The nature and nomenclature of these connections may vary from site to site (Boyd and Ellison, 2007: 211). The biggest evolution in the history of online social media platforms has happened in a little over 10 years $(2002-2015)$ changing the way of interaction between millions of people (Fuciu 2019:55). The nature of these connections differs according to each social network, although users commonly interact primarily with like-minded people already amongst their extended connections, instead of looking to interact with strangers (Susanto et al. 2021: 3). For more than four decades the internet has grown and spread to the extent that today it is an indispensable element in the communication and media environment of many countries, and indeed of everyday life, culture and society (Brügger et al. 2017: 1). In February 2005 the first version of the CIA website was online and it was the main platform where the association could keep its members updated about its projects and activities. ${ }^{2}$ The creation of the website was the first proactive attempt of the association to start building its name and its mission statement nationwide. In the same year of the foundation of the CIA, another company was born, a company that would have changed our way of interconnecting with people forever: Facebook. The creation of Facebook opened a new era of a more efficient way to interact between people and for private businesses to engage more easily with clients. The American social network only arrived in Italy in 2008 and it improved the way of advertising products, sped up the people networks, and news started spreading faster on a global scale level. ${ }^{3}$ In 2008 Facebook surpassed Myspace as the most-visited social media Web site. With the introduction of Live Feed, the company also took a competitive swing at the growing popularity of Twitter, a social network that runs a live feed of news service-like posts from members whom a user follows. Following the rapid growth of social networks worldwide, the first

\footnotetext{
${ }^{2}$ www.archeologi-italiani.it.

${ }^{3}$ https://www.britannica.com/topic/Facebook, accessed on 6 May 2021.
} 
CIA Facebook account was created in September 2008 during the AIAC (Associarione Internarionale di Archeologia Classica) ${ }^{4}$ congress in Rome. (Fig.1)

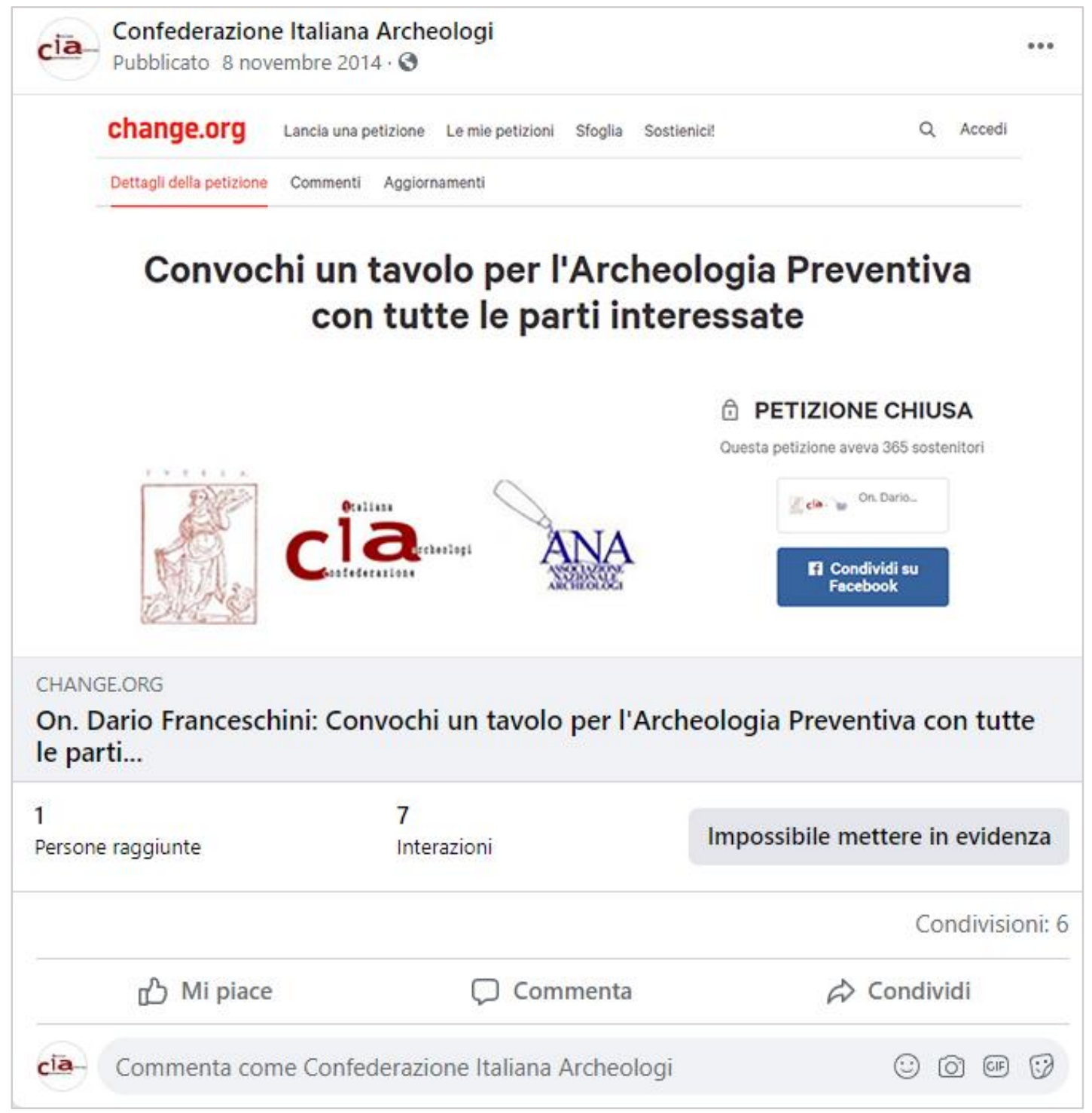

Figure 1. The first post published on the CIA Facebook page (8 November 2014).

A further step of the association into the social media world was the creation of the Linkedin page in 2010, the Youtube channel and the Twitter profile in 2011, and eventually the Instagram profile in 2017. Since then, things quickly changed and the exponential growth in the use of social media provided the opportunity to increase the engagement of the CIA with Facebook and Instagram users. The simple online Instagram photo-sharing became a powerful marketing tool to broaden the CIA contacts network, not only archaeologists but also a wide range of people with different backgrounds (Fig.2). This is what Haythornthwaite called 'Latent ties theory': adding any network-based means of communication - whether a new IRCchannel, a social support group, a Webboard or

\footnotetext{
${ }^{4}$ http://www.aiac.org, accessed on 8 May 2021.
} 
email listserv - lays the groundwork for connectivity between formerly unconnected others. Because such connectivity - by definition - brings together unconnected others, the latent tie structure has to be established by an authority beyond the individuals affected. Internet-based social support sites fit this profile. These are started by individuals with a particular interest in a subject (e.g. rare or chronic medical conditions) who may begin by posting information and providing the means for online discussion (Haythornthwaith, 2005).

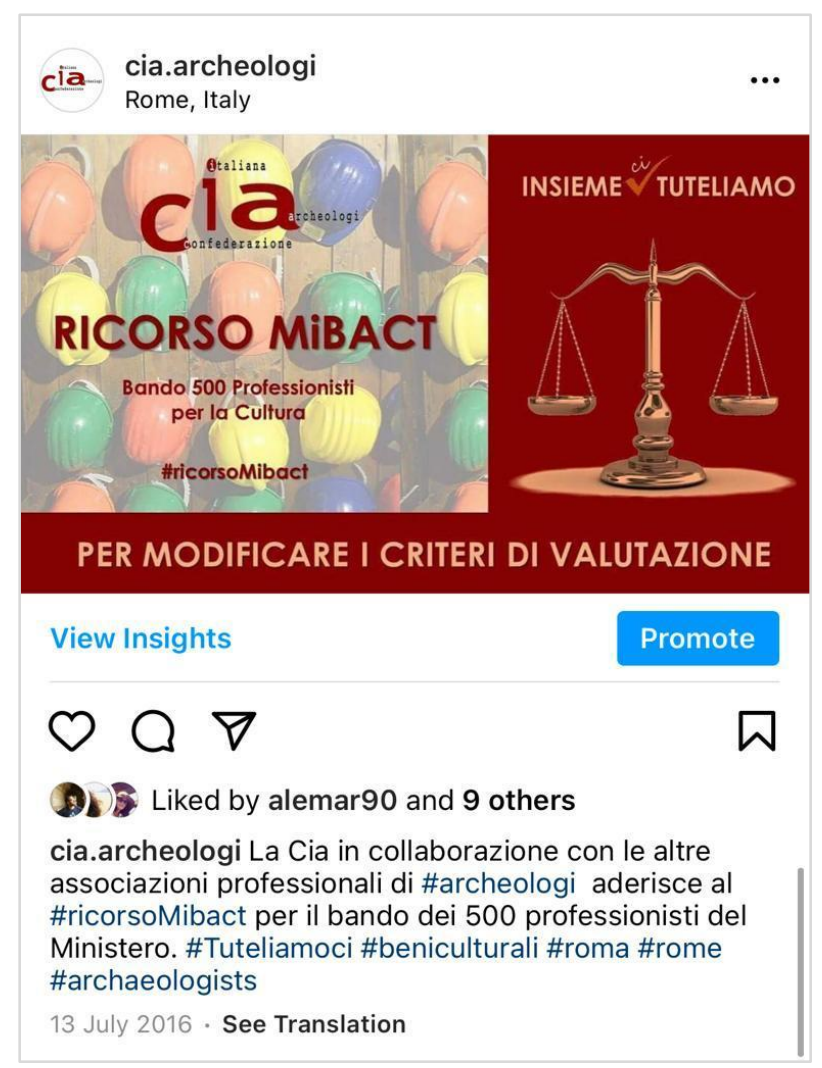

Figure 2. The first post published on the CIA Instagram page (13 July 2016).
Since 2016, as a non-profit association, the purpose of using social media was to inform its members of CIA activities, share information and communicate projects and events. The national assembly in November 2019 changed the way of how the CIA was going to approach the public and communicate to users. During the national meeting, the new CIA Communication Group was formed and the first task was to try to break these boundaries between the association and the general public, to raise interest in archaeology and the profession of the archaeologist, opening CIA vision to everyone. The new group faced new challenges during the forthcoming three years: trying to attract more archaeologists in becoming members of the association, involving them more in CIA activities and, increasing the association network trying to gain nationwide coverage through social media channels. To widen public engagement, the Communication group had to rethink the CIA as a brand and reshape the association interaction with the old users in terms of members loyalty and attract the new members with new and appealing contents. The main question was: could integrating social media as a public relations initiative help the association to gain a stronger audience engagement? The first attempt was adding mainstream connotations related to culture and heritage, in between the main activities posts of the association. The second step was to build a direct interaction with users and improve their experience on CIA social media pages creating a voice for both the association and the users, allowing them to feel appreciated, knowing that their comments or message are being noticed. This new attitude swiftly increased the number of contacts, especially on the Instagram profile where the growth of followers increased by 69 per cent in less than a year. In the first three months of 2020, this new method also boosted public engagement on Facebook by 10 per cent: insights data shows a growth of the Instagram followers of more than 2.500 and, on Facebook, the numbers are above 13.000 contacts. 
Maintaining a good online presence was eventually one of the key aspects that determined the growth of the CIA social media channels. The new concept worked well until the COVID-19 pandemic hit Italy at the beginning of March 2020. A few weeks into the lockdown all CIA members were called for an emergency meeting when it was realised how catastrophic the pandemic was and that the lockdown measures would last longer than initially expected.



Figure 3. \#CIAndremo project: cover image for the launch of the project on CIA social media pages.

\section{The \#CIAndremo project}

The \#CIAndremo project was established at the beginning of the first lockdown in March 2020 following the idea of a virtual tour of cities, cultural places, and archaeological sites to show Italian heritage, not only to archaeologists but also to a wider audience. Since the beginning of the pandemic, from March 12 until June 7, the CIA 36 videos with a photoslideshow format presenting places around the country from large cities, among them Rome, Venice, Milan, to small towns such as e.g. Tripi (Sicily), Soncino (Lombardy), and Monastir (Sardinia), from museums - MANN in Naples, the Museo Egizio in Turin - to archaeological sites - such as the Etruscan necropolis of Banditaccia in Cerveteri or Crustumerium (Rome) - (Fig.3). The rapid initiation of the project's design was key for publishing the first video only four days after the beginning of the lockdown. The starting point was the video of the city of Milan, located in one of the Italian regions most affected by the pandemic since January 2020 (Fig.4). Since the beginning, the purpose of \#CIAndremo was promoting Italian heritage via social networks, encouraging people to visit Italy after the pandemic restrictions ended. The central focus of every single production was describing the place with the eye of the author by telling a story based on personal memory. Through this project, we didn't only talk about heritage, but we added the human experience too. This is what Byrne called place attachment:

"once an object or a place is imbued with this affective valency it cannot simply be switched off [..] Some of us who work in the fields of archaeology and heritage studies are trying to get a better understanding of this kind of place attachment so that we can arrive at an approach to heritage conservation that preserves 

174).

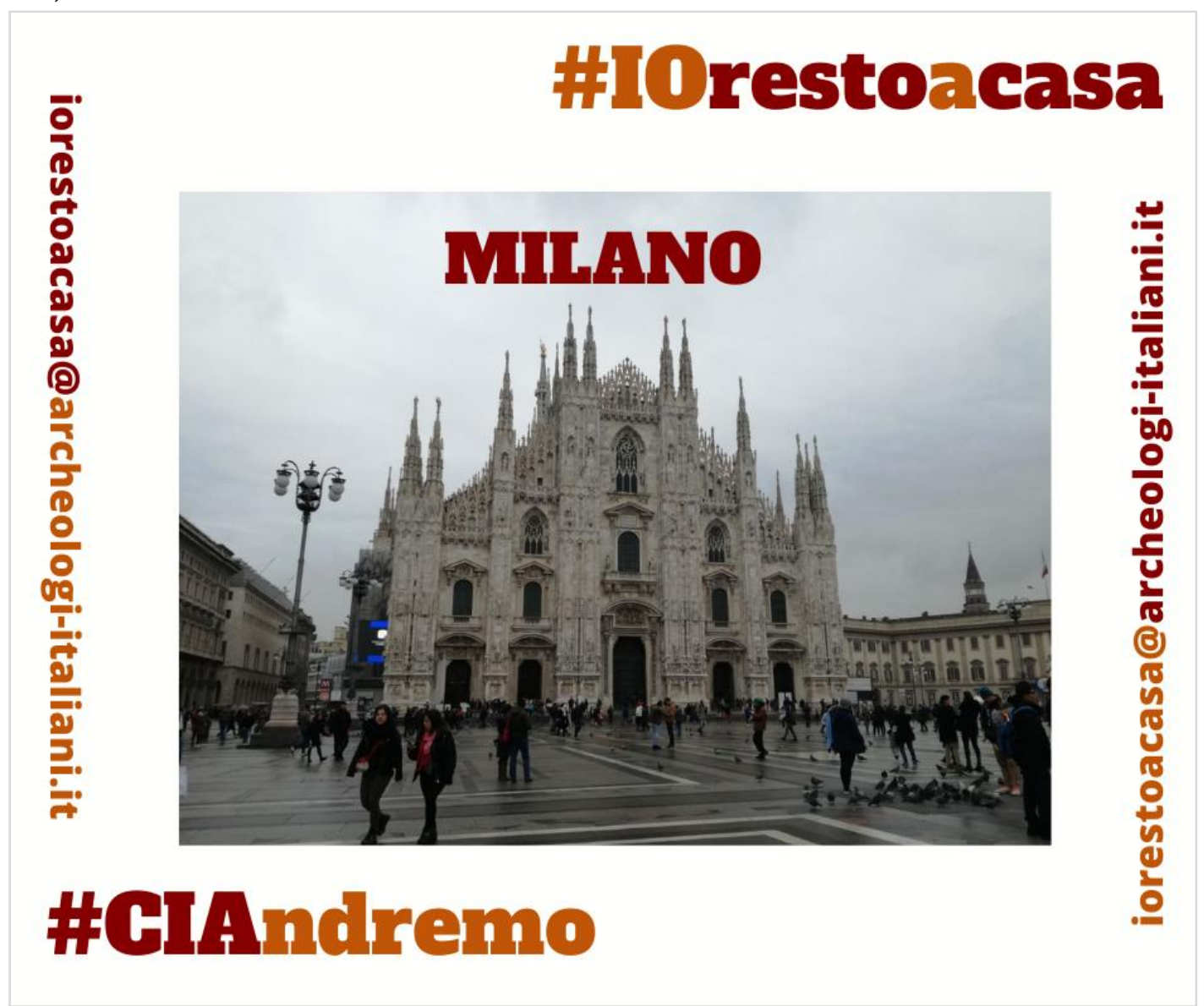

Figure 4. Cover image introducing the first video published about the city of Milan (11 March 2020).

The emotional aspect of every video played a major part in the success of \#CIAndremo, creating a connection between the history of the place and the feelings of the audience using the empathetic aspect as leverage. Another important aspect of \#Ciandremo's editing process was to keep the length of the video limited to no more than three minutes, in order to retain the viewers' attention. There is still not a primary study about the engagement rate based on the video length but, for example, the Pew Research Center (Pew Research Center: Journalism \& Media Staff 2012) reviewed the most viewed YouTube videos between January 2011 and March 2012 and found $~ 50 \%$ were less than 2 minutes and $\sim 82 \%$ were less than 5 minutes following the perception that video length was inversely correlated with capturing and holding viewer attention in business videos. That is, if the majority of videos are short, then it is likely that most popular videos are short, even if these data are only indicative (Welbourne 2015:4). Furthermore, descriptive texts were read aloud and recorded and that audio was added to the videos together with Italian and English captions, to reach a foreign audience and hearing-impaired people. Even before the pandemic, the starting point to connect with an ever-widening audience was to upgrade the CIA communication strategy on social media networks: promoting the association events on English speakers archaeological Facebook groups, translating some of the projects into English and adding captions to the videos on YouTube. The constant effort of the CIA communication group produced more than five hours of total views 
and the achievement of publishing the videos weekly through the CIA social platforms and, in particular, on national and European cultural groups and profiles. The enormous accomplishment of almost eighty minutes of videos in about three months was possible by dividing the many components of the project between the communication group members based on their individual skills.

\section{An example of community archaeology}

The target of an even wider audience led the CIA to develop an additional promotional campaign of the project, asking the viewers to share their experiences and personal memories of their favourite places. And moreover, the extension to lockdown restrictions surely helped increase the engagement with the users and so, as might be expected, most of the new contributors were CIA members supplemented by other professional archaeologists, and also users of the CIA network content to share their experiences. In a Community Archaeology perspective (Volpe 2020: 114-117) the places portrayed in this project had a geographical distribution that mirrored the situation of the CIA regional branches where members were active the most: Lazio (10 videos), Lombardy (5 videos), Sicily (3 videos), Tuscany (3 videos). The remaining videos covered almost all the regions of Italy. As a consequence, these additional personal narratives provided a level of engagement on social media beyond initial expectations: the analysis of the insights of every single video on YouTube showed that sometimes less known archaeological sites like Crustumerium and Tusculum (Lazio) received more views than predicted. The unexpected outcome was obtained from an audience that was, somehow, personally connected with the two places. The intimate style of the narrative associated with the memory of an artist or the university archaeological project, produced a progression of the views overtaking famous places like Rome, Pompeii or the Museo Egizio in Turin. The level of interaction differs depending on the social network because every platform has its own style and nature, meaning rates of engagement vary greatly. Crustumerium and Tusculum have reached nearly 700 views while Rome 600, Pompeii and the Museo Egizio around 150 views on YT. On the contrary, for the same videos, IGTV did not reach the same level of views: Crustumerium reached 81 views and Tusculum reached 97 views; Rome reached 309 views, Pompeii 331, and Museo Egizio 275. These two videos showed a rise of the views that positively affected our small community response, and identified that personal storytelling was the most important way to communicate "da molti a molti", literally "many to many" (Ferraris 2017: 76). Therefore, \#CIAndremo proved to be a successful project of public archaeology or public-oriented archaeology in an attempt to develop and reform the niche nature of the subject so that archaeology can better engage the public (Matsuda 2004: 68) ${ }^{5}$. For the first time, the CIA stepped outside its traditional approach of engagement only with professionals and opened up to potential new digital users. The project became a landmark for a new way of communicating heritage and archaeology through the usage of a new social media structure and language overlaying the wellestablished role of the association among the professional community.

\footnotetext{
${ }^{5}$ Credit also goes, in order of appearance, to: N. Donati, A. Riva, N. Barocca, A. Abbadessa, D. Mancini, E. Mazzetti, G. Incammisa, F. Molteni, A. Pintucci, T. Magliaro, G. Pace, T. Iozza, M. Peris, A.C. Bellinato, V. Uglietti, F. del Fattore, M. di Fazio, F. Amoruso, C. Guastella, C. Speciale, D. Putortì, Progetto Tusculum, G. Rossi, E. Gusberti, C. Rizzo, A. de Rosa, F. dell’Era, S. Ricci, M. Maturo, I. Mucilli, S. Semeraro.
} 


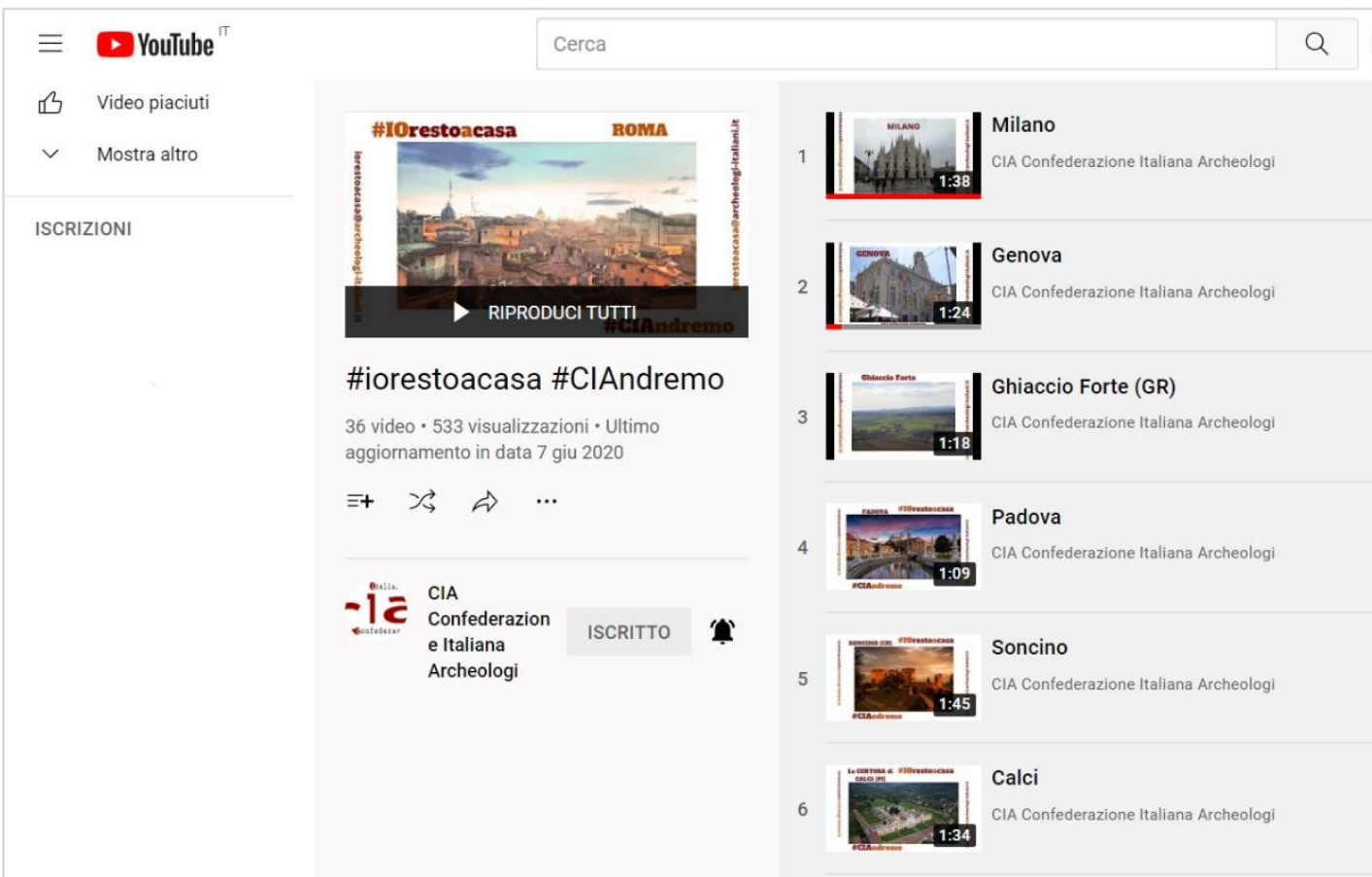

Figure 5. Screenshot of the CIA YouTube channel playlist.

\section{The use of CIA social media channels and some statistical data}

The videos of \#CIAndremo projects were published using all the CIA social networks: Facebook, Instagram Tv and YouTube. The only exception was the first video about the city of Milan published at the beginning only on Facebook. The main reason for not initially using YouTube was due to a larger CIA following on Facebook among the other social networks. Therefore, we could count on the existing Facebook audience already following our activities and we were confident our users would welcome this project positively in a unique moment where everyone was more online than usual. The good response received on Facebook after the publication of the first video about the city of Milan urged us to review our communication strategy and resume the association YouTube channel ${ }^{6}$. After being uploaded the video received 51 views in the first days and the subscriptions of the CIA YouTube channel grew by $22 \%$ in less than a week. The \#CIAndremo videos augmented the YouTube channel subscriptions by $68 \%$ by the end of July (Fig.5). At the end of the project on 7 July and, due to the entertaining nature of the videos, the CIA YouTube channel reverted to its supporting role for the association's main social media. A variety of positive outcomes were achieved via the \#CIAndremo project; for example, videos uploaded on a specific date like the one published on 21 April, the day of the foundation of Rome or the videos about museums published again during Museum Week ${ }^{7}$ when the project was published on Facebook Watch again. Moreover, the collaboration with other cultural organisations helped produce other videos, like the one about the Tusculum project (https://www.tuscolo.org) in collaboration with the Escuela Española de Historia y Arqueología en Roma-CSIC (https:/ /www.eehar.csic.es/), or the video on the archaeological site of Crustumerium linked to the second anniversary since the

\footnotetext{
${ }^{6}$ https://www.youtube.com/c/CIAConfederazioneItalianaArcheologi

${ }^{7}$ https:// museum-week.org, accessed on 8 Jul 2021.
} 
passing of the painter Serge Uberti (Gnetti 2012). The purpose was to reach a different audience using all these different social tools. Another example of the successful partnership was with the archaeological mission of the Università degli Studi of Milan about the Monastir Terra Sarda archaeological site in Sardinia. ${ }^{8}$ (Fig.6) In some cases, the post was successful thanks to the collaborative release of other media by the subject of the video itself like the peculiar case of the MANN in Naples that reposted the video on the official profile of the museum leading to a high level of user engagement. A direct benefit to this project was a drastic improvement in the time taken by the CIA communication group to arrange a whole project in a short time: the first lockdown began on 8 March and the first video was launched only three days later. The positive outcome of the \#CIAndremo project was featured in the Corriere della Sera, a highly circulated Italian newspaper, less than a month after the first publication of our videos (Garrone 2020). Throughout 2020, many similar initiatives were created by other organisations following a comparable format to the \#CIAndremo project with the sole purpose of promoting Italian heritage. For example \#ilmuseoincasaa, video project created by Musei in Comune Roma from 21 april 2020 until 21 February $2021^{9}$, or the projects of the Ministry of Culture (MiC): Viaggio in Italia. ${ }^{10}$

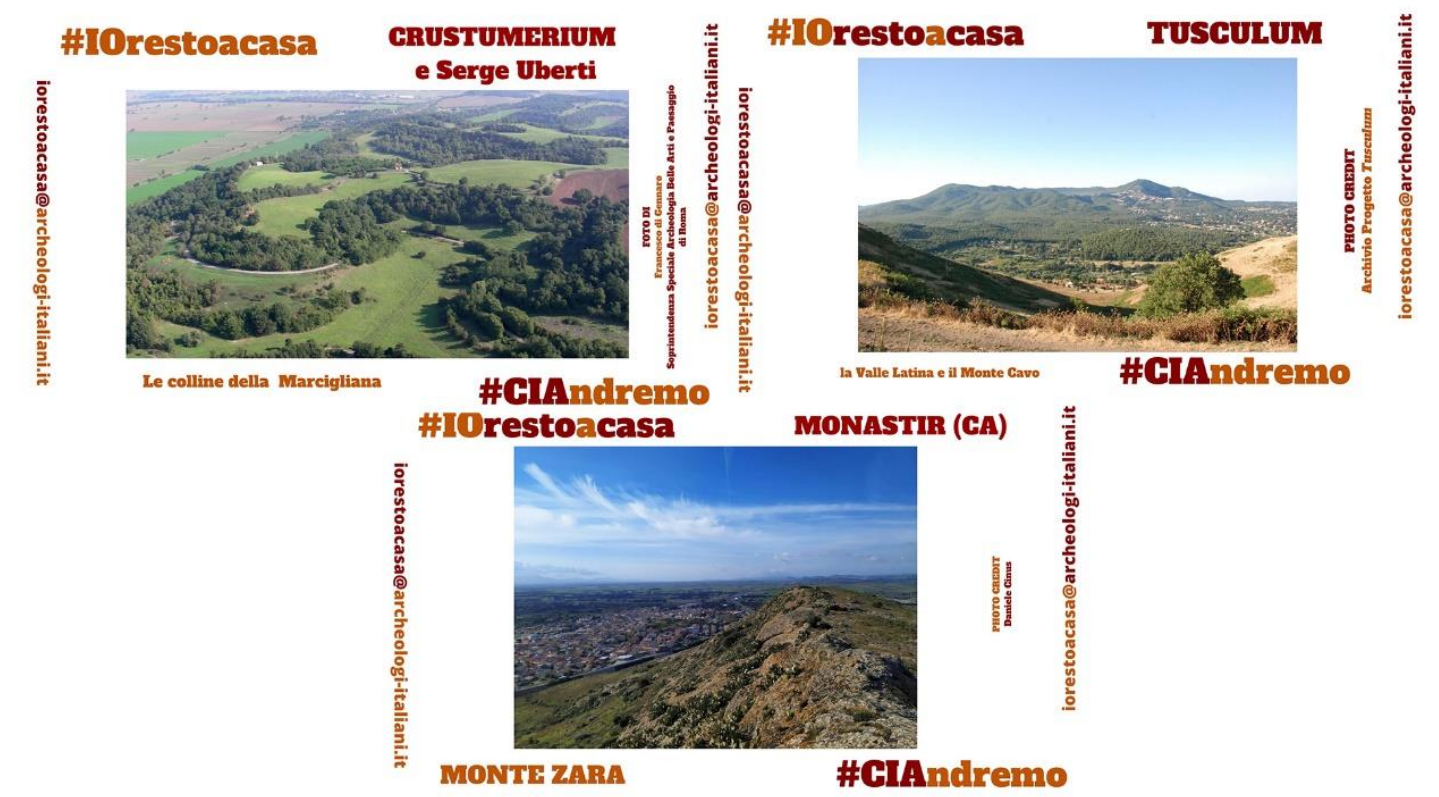

Figure 6. \#CIAndremo project: a photo collage of the archaeological sites at Crustumerium, Tusculum and Monastir. published

\section{Una domenica al museo (Sunday at the museum)}

\section{The reason for a weekly column about museums}

The second media project that is presented in this essay is called Una domenica al museo (Sunday at the museum), initially created for the Instagram profile of the association on 9

\footnotetext{
8 https://www.unimi.it/it/terza-missione/patrimonio-storico-e-culturale/scavi-archeologici, accessed on 12 Sep 2021.

${ }^{9}$ https://www.youtube.com/playlist?list=PLePsIYyhjO7b2PPDC4oHChFCqgmo3FHgC, accessed on 29 Aug 2021.

10 https://youtu.be/JaGE6EfQKdI, accessed on 29 Aug 2021.
} 
June 2019 with a post about the exhibition: "L'arte di salvare l'arte. Frammenti di storia d'Italia" opened from 5 May until 14 July 2019 at Palazzo del Quirinale in Rome. The project was born for the sole purpose of gaining new followers and on 16 March 2020 it made its debut on the Facebook pages of the association following the \#Ciandremo project involved the following museums: MANN in Naples, Centrale Montemartini in Rome, Museo delle Navi Antiche in Pisa, Musei Civici di Reggio Emilia and Museo Egizio in Turin. From 24 May 2020 it became a permanent weekly appointment on both social media channels. The initial outline of this project was to introduce a museum, or part of it, to the followers posting ten pictures (a limit for Instagram pots), accompanied by a short descriptive text in Italian and English. So, this weekly corner was designed to show the chosen museum from the visitors' point of view. Some of the photos portray peculiar finds on display or a portion of the exhibition layout as if the visitor was physically present and leave a memory on its social media page. The pictures are followed by a short text (2.200 words is the Instagram character limit) where we give some information about the museum's history and collections. Both on Facebook and Instagram the posts' hashtags are varied but related to the museum's network, tagging cultural institutions like the MiC (Ministero della Cultura), the Regional Directions of Museums, ICOM (International Council of Museums) and other institutions. The final purposes are those of trying to stimulate the curiosity of the virtual audience to visit the museum and, in the meantime, increasing the cultural and heritage network involving the institutional subjects in the project. Since the beginning, Una domenica al museo entered the museum's doors to offer insight on collections, both permanent and temporary and put a spotlight on the most interesting and curious artefacts to the social users. This virtual approach to the world of archaeological museums - from large and national to the small and local, both Italian and European - also built people's awareness of the territory where they live and what it has to offer from a cultural point of view. Sometimes the column repeatedly visits the same museum to show if there is something new to discover, such as a new exhibition or renovation. One of the many reasons why the CIA Communication Group started a specific column was also because museums are on one of the workplaces where numerous Italian archaeologists are employed so, as a professional association, it is the association's job to advocate for them. Raising consciousness about the archaeologist's profession is one of the aims towards the growth of an archaeological culture not just among professionals but also among the general public in accordance with the approach of C.R. McGimsey based on the heritage and the workers protection (Volpe, 2020: 25-26). Entering a cultural workplace was also a way to bring the behind the scenes work of the museum staff and specialists to a wider audience. We are sure that promoting archaeological culture in contemporary society will grow awareness towards the preservation of heritage.

\section{The evolution of Una domenica al museo duting the pandemic}

Since the start of the first lockdown in March 2020, this weekly format has questioned how to communicate the museums offer behind closed doors. A topic that was already brought up by professionals and scholars during the first pandemic wave when museums were closed (Bennardi 9 May 2020; Dal Maso 2021). During the first few weeks of the emergency, there still was the illusion that the pandemic could have been solved rapidly so the column was still publishing photos of the museums and exhibitions, now closed, 
with the usual format, believing in a quick reopening. One of the posts published was our visit at Museo di Archeologia Ligure in Genova - Pegli (Fig.7) and the exhibition: "Gaetano Chierici. Metodo e scienze all'origine degli studi di preistoria" opened the 31 st of January 2020 until the 1 st of November 2020 at Musei Civici di Reggio Emilia.
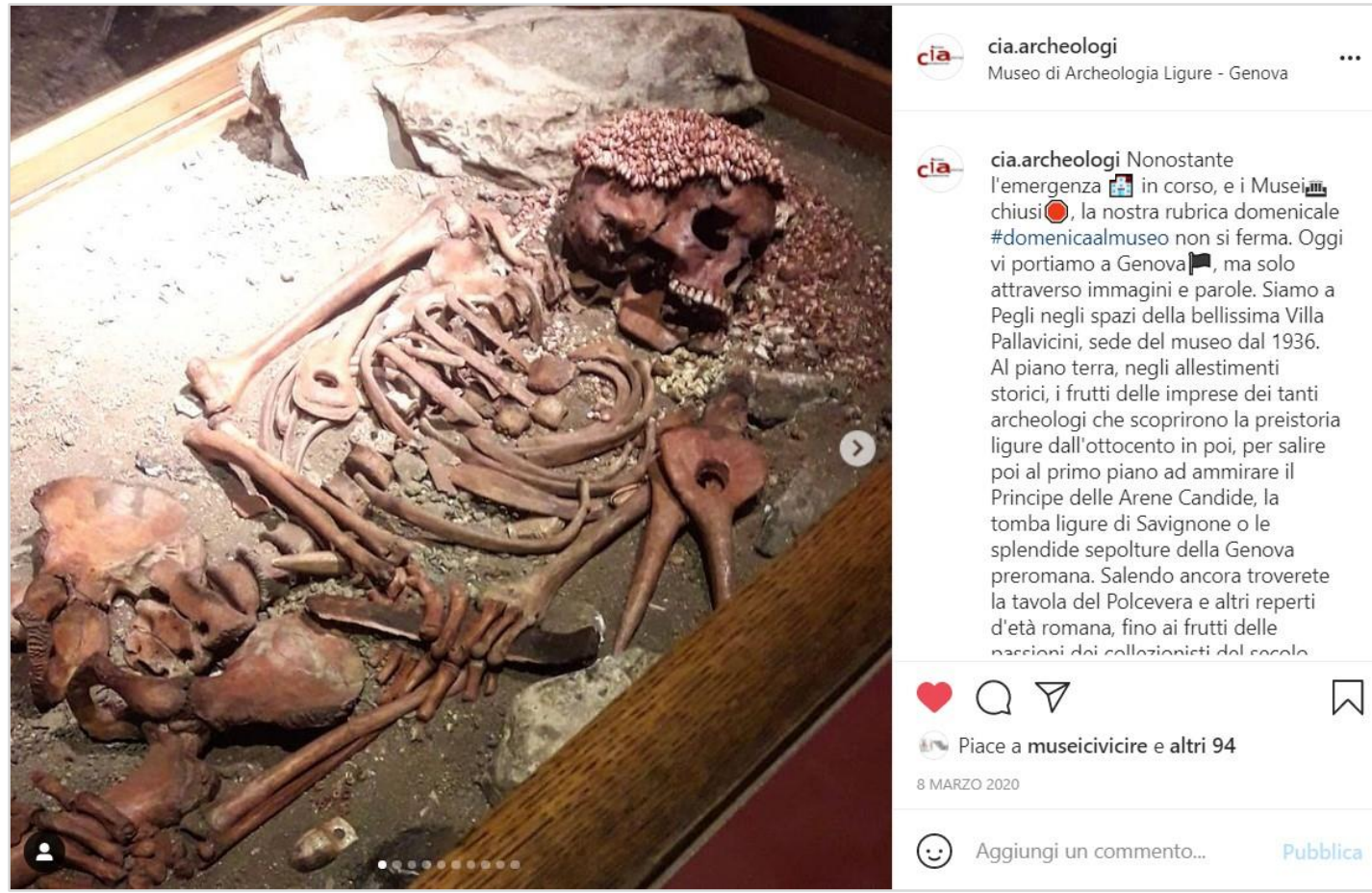

tiv Piace a museicivicire e altri 94

-.) Aggiungi un commento.

Figure 7. Una domenica al Museo (8 March 2020): The young prince of the Arene Candide, Upper Paleolithic, Museo di Archeologia Ligure, Genova Pegli (courtesy of the museum).

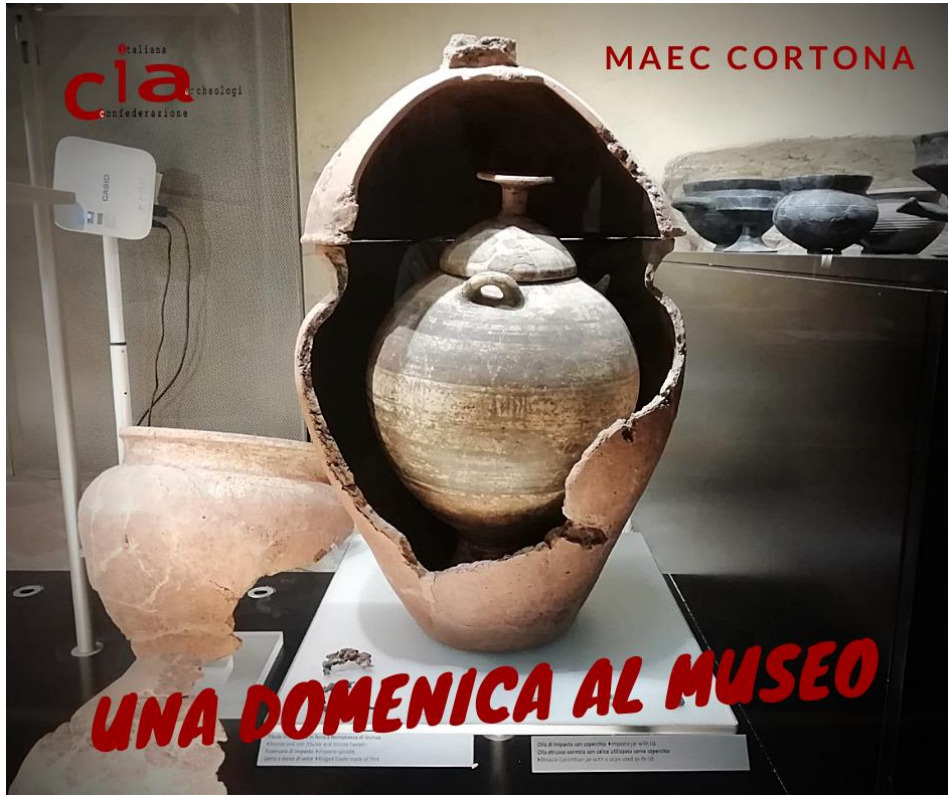

Figure 8. Una domenica al Museo (2 August 2020): cover image MAEC at Cortona (courtesy of the museum).
The lockdown restrictions imposed by the Italian government from 9 March changed the plans of the CIA Communication Group that started to work on the new original project \#CIAndremo by putting on hold all the other activities, including Una domenica al museo. The ease of the lockdown in May allowed the reopening of the museums in some of the Italian regions and one of the first to reopen was the Museo Internazionale della Ceramica of Faenza. At this time the Sunday's corner allowed us to talk about the COVID-19 health and safety measures put in place by museums. The 
health and safety theme was carried on when the column was published regularly over the summer (Fig.8).

However, on 8 October 2020, the Italian government announced a second lockdown and all the cultural institutions closed their doors again. The main issue was to carry on with Una domenica al museo's corner whilst the museums were closed again. One of the concepts was to upload pictures of old exhibitions like the old 2014 display in the protohistoric section of Museo Nazionale di Parma trying to raise the interest of bringing the public on a virtual tour until the reopening. The concept was soon discarded and the new idea of a photo patchwork of the museums' closed doors came up and was carried out for four weeks (Fig. 9). With the lockdown still in place the Sunday's corner shifted the attention on what was going on behind those closed doors, on how the museums were dealing with the closure and what they were doing to make virtually accessible their collections to the public.

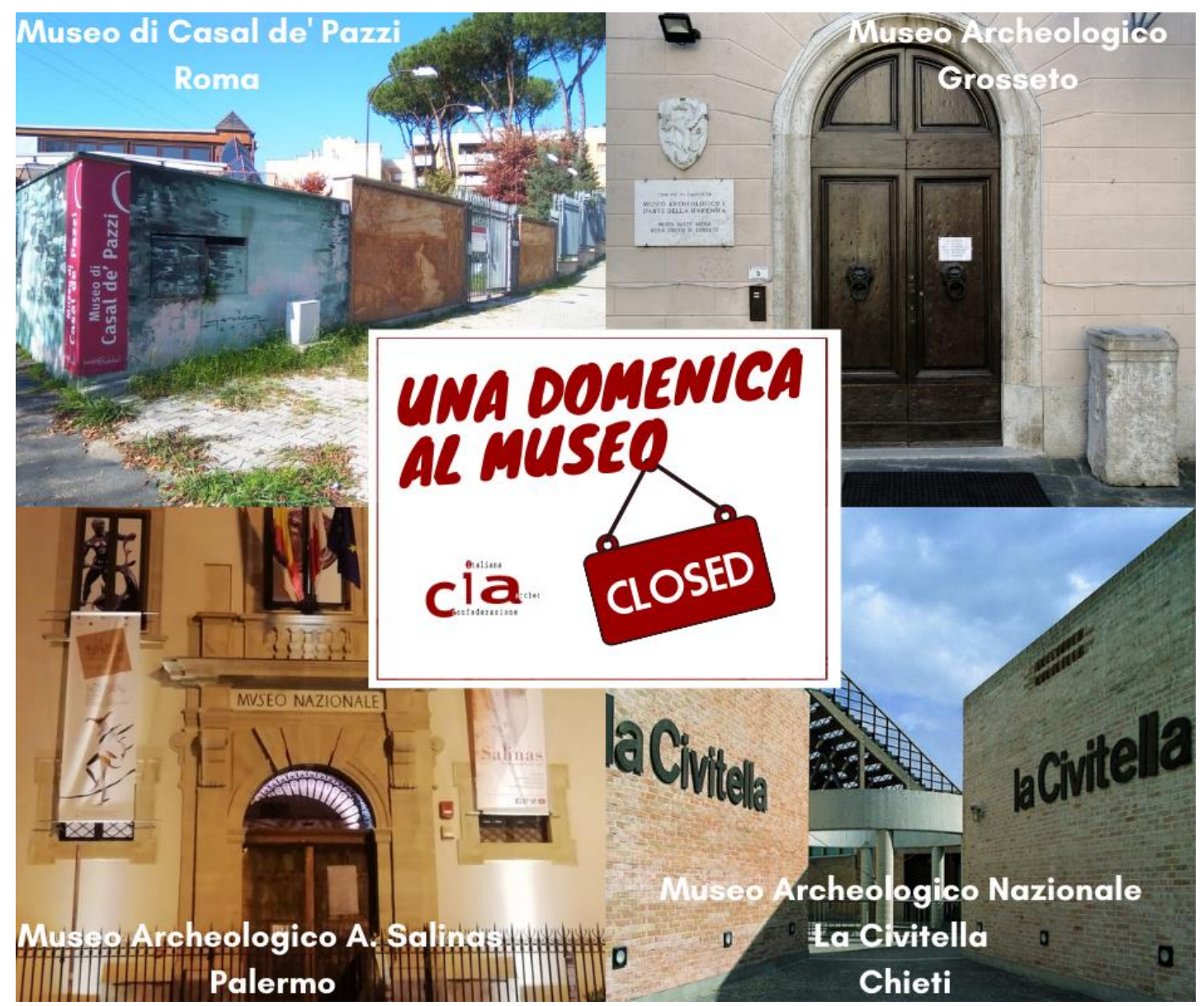

Figure 9. Una domenica al Museo (8 November 2020): The doors of the following museums: Museo di Casal de Pazzi in Rome; Museo Archeologico e d'Arte della Maremma in Grosseto; Museo Archeologico Regionale Antonio Salinas in Palermo; Museo Archeologico Nazionale La Civitella in Chieti.

We presented the educational projects of some museums like the "Scuola diffusa" by the Musei Civici of Reggio Emilia, the one of the Civico Museo Archeologico in Camaiore, the online event "Bevi Rosmunda.... tutta la verità sulle donne longobarde" created by Spazio Aster at the Civico Museo Archeologico in Milano and "Il fornaio Euriace e il calzolaio Giulio Elio si raccontano" at Centrale Montemartini in Roma. We also posted some of the museums virtual 
tours like the ones at the Museo delle Navi Antiche in Pisa, at the Mercati di Traiano in Roma, at the Museo delle Antichità in Torino, at the Museo nazionale d'Abruzzo. In the end we presented the virtual projects for Google Arts \& Culture created by the Musei Civici di Reggio Emilia (Fig.10) and by the Centrale Montemartini in Rome. The format aimed to illustrate the digital initiatives put in place by museums (for a synthetic guide about the digital initiative Zuanni 2020) and trying to appeal to the public their collection through virtual tour guides, online exhibitions, the museum staff at work or presenting a specific collection. For the first time, CIA collaboration with the communication offices of these museums led to an improvement of the public engagement on the social media pages. Nevertheless, as the second lockdown didn't seem to end with the new year, the CIA communication group decided to temporarily stop the weekly column. With the new year only occasional posts were published, with the new hashtag \#vistidavoi (seen by you), where it was asked both the general followers and the professionals to send pictures and describe their favourite museums like the Direzione Regionale Musei dell'Umbria that joined the initiative. In May 2021 the column slowly started again the publication of the cultural institutions trying to involve the local museums, the most affected by the pandemic ${ }^{11}$. The commitment of the association was that of promoting these small cultural realities that the spread of the SARS COVID-19 virus led to the risk of permanent closure, despite being an important part of the heritage network inside the complex Italian museum system (ISTAT 2019: 7).

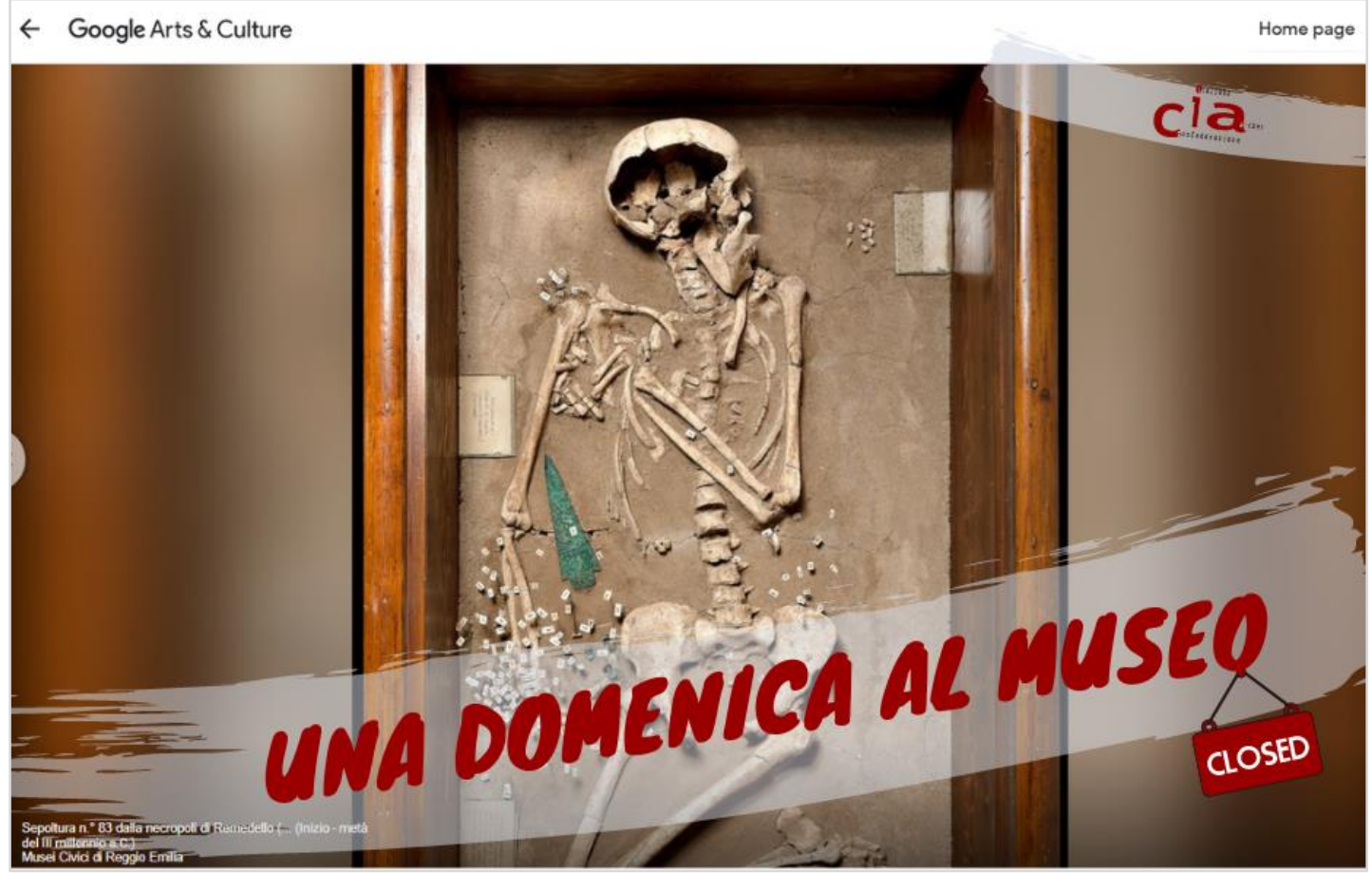

Figure 10. Una domenica al Museo (13 December 2020): Digital project for the online exhibition "Il primo metallo. La scoperta della necropoli dell'Età del Rame di Remedello”. Musei Civici Reggio Emilia. Tomb 83 from the Remedello necropolis, Copper Age. Edited from the original photo of C. Vannini (courtesy of the museum).

\footnotetext{
${ }^{11}$ https://www.archeologi-italiani.it/wp-content/uploads/2021/06/Assemblea-Nazionale-2021documento-finale.pdf (accessed on 29 Jun 2021) and ICOM survey: http://www.icom-italia.org/musei-ecovid-19/ (accessed on 29 Jun 2021).
} 


\section{Data analysis of the public engagement during the pandemic}

Since 2019 una domenica al museo slowly became a solid pillar among the regular social media activities of the CIA. The average likes on a Sunday post were usually between 40 and 100 on Instagram as much as on Facebook, excluding rare posts where the numbers were higher, around 180 (186 for the visit of the 2 of August 2020 at MAEC of Cortona and 91 likes on Instagram; 174 for the Museo Archeologico of Acqui Terme and 66 likes on Instagram). It is thus not surprising that the numbers are not particularly elevated as followers are mostly a niche audience made of professionals and archaeology enthusiasts. The data collected until now considered the difficulties of shifting the column concept during the first and the second lockdown and the impossibility to differentiate the numbers of likes from the general public to the ones of the members. The result is an average data estimating on different record numbers. The first datum refers to 11 posts published in 2019 and 4 posts at the beginning of 2020 before the pandemic hit the country. The 2019 ones were posted only on our Instagram page presenting Italian, European and also American museums, telling the public about their permanent collection and temporary exhibition. Estimating an Instagram post coverage between 411 and 667 users with an average of 468 followers, and interactions (likes and comments) between 22 and 83 with an average cover of 49 . As an example, we can make a comparison between two of the museums presented on the Sunday column at the beginning of 2020, before the first lockdown: the Museo di Archeologia Ligure in Genova Pegli (coverage 518 and interactions 44) and the exhibition in memory of Father Gaetano Chierici at the Musei Civici in Reggio Emilia (coverage 645 interactions 96). These data show the average community engagement of Una domenica al museo before the COVID-19 pandemic and without the \#stayathome factor that helped the Sunday column to reach more viewers. Starting from 11 March 2020, the first lockdown, the engagement data increased on the CIA social media pages thanks to the launch of the parallel original project \#CIAndremo that interconnected with Una domenica al museo through the videos of 5 museums on Instagram IGTV, FB Watch and YouTube. The easing of the lockdown restrictions after 24th May 2020 led Una domenica al museo to resume its regular weekly format until 1 November 2020. In addition to the description of the museum, the 24 posts published during this period of time, described the new guidance and safety measures put in place by the cultural institutions following the government guidelines: social distancing, mandatory face masks, pre-booking. In this segment between the first and the second lockdown, there are mainly Italian museums, but there are also European ones like the British Museum in London or the Celtic-Roman site of Magdalensberg in Austria, so the public is also updated about the new museum's regulations. The Instagram insights during this phase show a wider interaction from 29 up to 100 with an average of 57 . Also, the coverage data were rising with an estimating average of 566, thanks also to the constantly increasing number of followers since the beginning of 2020. On Facebook, the interactions fluctuated from 27 to 209 with an average of 83 whilst the coverage was between 1193 to 9864 (average 3872). This engagement increase must take into account some factors including the greater number of CIA Facebook friends than the Instagram followers and the ease of sharing Facebook pages compared to the Instagram feed repost. The insights charts show an increment of the engagement during the second lockdown starting in November 2020 with two sets of four posts each: the first one was the concept 
"museums behind closed doors" and the second one was a collaboration with four museums showing their online digital activities. The engagement data of Instagram were the highest with coverage from 566 to 652 whilst on Facebook it goes down only a little from 3872 to 3729 therefore in line with the connection numbers average. Interactions on Instagram also increased from 57 to 68, unlike Facebook that dropped from 81 to 66.

According to the authors the data do not present substantial differences before and after the lockdowns. However, there was a consolidation of the Sunday column in 2020 with more interactions with the online community. Nevertheless, the single insights differences readable within the periods are more related to the choices made on the single posts than an increase due specifically because of the Covid-19 pandemic. Even if the Communication Group had already decided to improve all their social media offer before the pandemic, Una domenica al museo included, we cannot rule out the factor of exponential growth of the use of the internet during the lockdown. So, how did the Covid-19 pandemic affect Una domenica al museo performance on social media? If we analyse the numbers they are not so relevant at all, between 5 and 2 per cent, but if we talk about the format changes during the lockdowns we can see the intensification of engagement of a wider audience that came across the CIA association for the first time. Thanks to this column, these new users that were already active on the museums' social pages, interacted for the first time with the association. The importance of the images, the double language descriptions and the links connections to the museums' websites were also the key elements to create this dynamic connection with these new followers that also appreciated the visibility of their favourite institutions. In addition to the post layout, the publishing time and the numbers of sharing determine the following coverage and interactions. During the pandemic una domenica al museo created an unexpected outcome: the awareness in the online community of cultural problems with deep roots in Italy following the closure of the museums (Internazionale 11/17 dicembre 2020 • Numero 1388: Chiuso! Dal cinema ai teatri, dai musei alla musica. Il mondo della cultura lotta per sopravvivere alla seconda ondata di contagi). The loss of these cultural spaces brought up other issues, not only economic problems but also a perceived sense of disregard from the government institutions. As a matter of fact, in the last few years, the government policies concerning the cultural sector were focused only on the maintenance aspect of the heritage, highlighting the scarcity of new financial investment along with the shortage of staff at the Ministry of Culture. As a consequence of all those years of neglect, the already small financial resources provided to the heritage have been further reduced by the COVID-19 crisis (Lilli 2021). Moreover, losses between 60 and 80 per cent are expected subsequently from the decline in the international tourist economy in 2020 (Travkina and Sacco 2020: 47). In between the global pandemic crisis and the Italian one, our small project aimed to raise awareness about the importance of museums and the potential that cultural institutions have, mainly with the regional territory and the local communities. The pandemic allowed us to open a dialogue, not only between the CIA members, but also towards a broader audience. During these difficult times, the CIA interactions regarding this column grew exponentially and the improvement of Una domenica al museo helped people to come in contact with the association, discovering its philosophy and its constant effort of improving the working conditions of our category. 


\section{Conclusions}

The COVID-19 pandemic changed people's daily routine and their activities were shifted online overnight. For this reason, social media became an even more important tool of connections, and we believe that it helped the association expand its network and, more importantly, increase the number of annual subscriptions in 2020,30\% more than in 2019. The data gathered in this study are the main subject to grasp a deeper understanding of the role of digital public archaeology during the pandemic. The two projects presented in this article played an essential role in strengthening the CIA position among the online community, and the growing engagement on social media is the first step for the association to carry on its main activities with greater effort. During these challenging times, the \#CIAndremo project was a collaborative work involving not only the CIA communication group but also the CIA members and the association extended social media network: not only archaeologists or professionals in the heritage sector, but also people connected to CIA members and users interested in gravitating in the cultural world. The project success was mostly due to two key factors: the timing of the video release after three days into the national lockdown that grabbed the attention of the community and the originality of the project itself. A product that was not just a descriptive narrative of a place, but it triggered the emotional response of an individual and also left a sense of curiosity to discover a city, a museum or an archaeological site once the lockdown was over. Meanwhile, \#CIAndremo connected the online community to a small part of the Italian heritage and raised the consciousness of its outstanding cultural and artistic value. Since 2019, Una domenica al museo slowly became a solid pillar among the regular activities of the Confederazione Italiana Archeologi. During these years it became a weekly key appointment on the association's social media pages, and it allows one to discover the members and colleagues workplaces and their unremitting commitment to promoting and enhancing the essential role of museums in Italy. From a Public Archaeology perspective, the column was always an important means of communication for the CIA to contact new users and reconnect with old ones, while also conveying to the public the importance of heritage and informing them of cultural events and archaeology news. With these two projects, we started to open the CIA to several new possibilities of promotion and engagement with people and, this new vision, where archaeology embraces technology, offers endless opportunities for highly personal interaction with the past in a future perspective. This digital form of Public Archaeology encompasses methods for engaging the Internet-using public with archaeology through Web and mobile technologies, as well as social media applications, and the communicative process through which this engagement is mediated online. (Richardson 2013: 4). To share and discuss archaeology and heritage in a digital form through the web and social media is a fairly new practice and the communicative part in an ongoing process. In conclusion, "Archaeology, whatever its objectives are, can no longer remain in the academic domain alone, separate from the external interests of modern society. Any archaeological activity inevitably contains and entails a value judgement, which, by definition, is never disinterested and should therefore be considered from a sociological point of view. It was this realisation that gave archaeologists an impetus to engage not only with fellow archaeologists but also with the multi-faceted public". (Matsuda 2004: 67) 


\section{References}

BENNARDI D. 2020. La fruizione culturale nel post covid19, @Artedata Sas, webinar online 9 May 2020.

Boyd D., ElLISON N. 2007. Social Network Sites: Definition, History, and Scholarship. Journal of Computer-Mediated Communication, Volume 13, Issue 1, 1 October 2007: 210-230, https://doi.org/10.1111/j.1083-6101.2007.00393.x

BozZA C. 2020. Coronavirus, \#iorestoacasa spopola in Europa. L'inventore Sensi: «Idea di mio figlio, troppi ragazzi in giro». Corriere della Sera 12 Mar 2020. Accessed on 4 June 2021. https://www.corriere.it/politica/20_marzo_12/coronavirus-iorestoacasa-spopolaeuropa-1-inventore-sensi-idea-mio-figlio-troppi-ragazzi-giro-7c7c753a-645c-11ea-90f7c3419f46e6a5.shtml

BrüGger N., Goggin G., Milligan I. \& SCHAFER V. 2017. Introduction: Internet histories, in: Internet Histories, 1:1-2, 1-7.

https://doi.org/10.1080/24701475.2017.1317128

BYRNE D. 2019. Affective afterlives: public history, archaeology and the affective turn. in: ASHTON P. \& TRAPEZNIK A. (eds.) What is public history globally? : working with the past in the present. London; New York: Bloomsbury Academic: 173-186.

Dal Maso C. 2021. Musei e comunicazione digitale: cosa ci ha insegnato il 2020?

Archeostorie. Accessed on 21 Aug 2021. https://www.archeostorie.it/musei-ecomunicazione-digitale/

FERraris M. 2017. Postverità e altri enigmi. Bologna: Il Mulino.

FuCIU M. 2019 The Rise of Instagram - Evolution, Statistics, Advantages And Disadvantages. Revista Economică 71:4.

GARRONE L. 2020. «\#CIAndremo»: siti archeologici a portata di un clic. Corriere della Sera 4 Aprile 2020. Accessed on 7 Sep 2021. https://roma.corriere.it/digitaledition/CORRIEREFC_ROMANA_WEB/2020/04/04/15/pciandremo-siti-

archeologicip-pa-portata-di-un-clicp_U3180135761519PW.shtml

GNETTI G. 2012. Art-cheologia Serge Uberti, l'esperienza di Crustumerium. Accesed on 9 Aug 2021.

https://www.zetema.it/wp-content/uploads/2012/12/cs-Crustumeriumx.pdf

HAYTHORNTHWAITE C. 2005. Social networks and Internet connectivity effects. Information, Communication, \& Society, 8(2): 125-147.

ISTAT 2019. Anno 2017, I Musei, le aree archeologiche e i monumenti in Italia, 29 gennaio 2019. https://www.istat.it/it/files//2019/01/Report-Musei_2017_con_loghi.pdf

Leiner B., Cerf V., Clark D., Kahn R., Kleinrock L., Lynch D., Postel J., Roberts L. \& WolfF S. 2009. A Brief History of the Internet. Computer Communication Review 39: 22-31. 10.1145/1629607.1629613.

Levush R. 2014, Legislation Protecting Italian Cultural Heritage. 4 Sep 2014, Accessed on 7 Jun 2021. https://blogs.loc.gov/law/2014/09/legislation-protecting-italiancultural-heritage/

LILLI M. 2021, La Corte dei Conti boccia le politiche culturali del Mibact: "Risorse stanziate in ritardo, carenza di organico e fondi non spesi”. Il fatto Quotidiano del 5 gennaio 2021. Accessed on 1 Sep 2021.

https://www.ilfattoquotidiano.it/2021/01/05/la-corte-dei-conti-boccia-le-politiche- 
culturali-del-mibact-risorse-stanziate-in-ritardo-carenza-di-organico-e-fondi-nonspesi/6055177/

MANDARANO N. 2021. Musei e media digitali. Roma: Carocci.

Matsuda A. 2004. The Concept of 'the Public' and the Aims of Public Archaeology. Papers from the Institute of Archaeology 15: 66-76.

Pew Research Center: Journalism \& Media Staff 2012. A New Kind of Visual News. 16 Jul 2012. Accessed on 6 Jul 2021.

https://www.pewresearch.org/journalism/2012/07/16/youtube-news/.

Richardson, L. 2013 A Digital Public Archaeology?. Papers from the Institute of Archaeology, 23(1): 10: 1-12, http://dx.doi. org/10.5334/pia.431

SANFELICI M. 2020. The Italian Response to the COVID-19 Crisis: Lessons Learned and Future Direction in Social Development. The International Journal of Community and Social Development. 2020; 2 (2): 191-210. https://doi.org/10.1177/2516602620936037 Susanto H., Fang Yie L., Mohiddin F., Rahman Setiawan A.A., Haghi P.K. \& SETIANA D. 2021. Revealing Social Media Phenomenon in Time of COVID-19 Pandemic for Boosting Start-Up Businesses through Digital Ecosystem. Appl. Syst. Innov. 2021, 4, 6. https://doi.org/10.3390/asi4010006

TRAVkina E. \& SACCO P. 2020. Shock cultura: COVID-19 e settori culturali e creativi. OECD.https:/ /read.oecd-ilibrary.org/view/?ref=136_136489-

igqp5v2dxn\&title=Shock-cultura-COVID-19-e-settori-culturali-ecreativi\&_ga $=2.139614003 .1839236809 .1637005353-219408288.1637005353$

VolPe G. 2020. Archeologia pubblica. Metodi, tecniche, esperienze. Roma: Carocci.

Welbourne D. \& Grant W. 2015. Science communication on YouTube: Factors that affect channel and video popularity. Public understanding of science. Bristol, England.

ZuAnNi C. 2020. Museum digital initiatives during the Coronavirus Pandemic. Accessed on 5 May 2021. https://digitalmuseums.at/index.html 
44 Nicoló Donati et Al. 